\title{
Asymmetrical cross-language priming effects
}

\author{
CATHARINE W. KEATLEY \\ Tilburg University, Tilburg, The Netherlands \\ JOHN A. SPINKS \\ University of Hong Kong, Hong Kong \\ and \\ BEATRICE DE GELDER \\ Tilburg University, Tilburg, The Netherlands
}

\begin{abstract}
Three experiments were conducted to examine cross-language priming in bilinguals. The first was a cross-language primed lexical decision task experiment with Chinese-English bilinguals. Subjects made lexical decisions about primary associate targets in the two languages at the same rate, but priming occurred only when the prime was in their first language (L1), Chinese, and the target was in their second language (L2), English. Experiment 2 produced the same pattern of asymmetrical priming with two alphabetic languages, French and Dutch. In Experiment 3, the crucial stimuli were translation equivalents. In contrast to the results of Experiments 1 and 2, priming occurred across languages in both the L1-L2 and L2-L1 conditions. However, this priming was also asymmetrical, with more priming occurring in the L1-L2 condition. A tentative separate-interconnected model of bilingual memory is described. It suggests that the representations of words expressed in different languages are stored in separate memory systems, which may be interconnected via one-to-one links between some translation-equivalent representations as well as meaning-integration processes.
\end{abstract}

Bilinguals are able to communicate in either of two languages without experiencing constant intrusions from the inactive language. Yet when a bilingual learns something via one language, there appears to be access to that knowledge via the other language. How can the language systems be kept separate in practice and still share the same information? Are the languages represented as separate, independent modules in memory? Or, are all languages represented in a shared, interdependent semantic module? These questions have important implications for an understanding of bilingual behavior and for more general models of memory and representation.

In 1963, Kolers formalized the question and integrated it into psychological issues of representation by proposing a shared-separate dichotomy. He suggested that the representations of words expressed in different languages either are stored in discrete independent memory systems or take totally abstract forms, such as propositions, and are shared by words in the two languages.

We would like to thank the staff of Hong Kong University who served as subjects in Experiment 1 and the students and staff of the Center for Life and Learning of Louvain University for their help in carrying out Experiments 2 and 3. We would also like to thank Annette de Groot and David Balota for their comments on earlier versions of the paper, as well as Mary Potter, Judith Kroll, and a third reviewer for their comments on this paper. Correspondence should be addressed to $\mathrm{C}$. W. Keatley, Department of Social Sciences, Tilburg University, P.O. Box 90153 , 5000 LE Tilburg, The Netherlands.

-Accepted by previous editor, Margaret Jean Intons-Peterson
Evidence for a shared-store model was found in experiments that demonstrated transfer of learning and interference across translation equivalents (Lopez, Hicks, \& Young, 1974; Lopez \& Young, 1974; McLeod, 1976; Young \& Saegert, 1966; Young \& Webber, 1967), as well as in experiments demonstrating that rate of recall of translation-equivalent words was the same as or better than rate of recall for within-language repetitions (Glanzer \& Duarte, 1971; Kolers, 1966). Evidence also was found for a separate store model. Subjects experienced a release from proactive interference in recall when the language of items on a list was changed (Goggin \& Wickens, 1971). In addition, subjects were able to recall the languages of items from bilingual or multilingual lists (Rose \& Carroll, 1974; Saegert, Hamayan, \& Aymar, 1975).

Other research, however, suggested that neither model explained bilingual behavior adequately (for a review of this literature, see Keatley, 1992). Studies using primary associate production (Kolers, 1963; Macnamara, 1967; Taylor, 1971), the Stroop color-word test (DalrympleAlford, 1968; Dyer, 1971; Preston \& Lambert, 1969), and organization of recall of items in bilingual lists (Champagnol, 1975; Nott \& Lambert, 1968) demonstrated that while within-language effects may be stronger, betweenlanguage effects occur too.

Two models were proposed to explain these data. Both are offshoots of Paivio's dual-coding model of memory for images and words (Paivio, 1971, 1986; Paivio \& Begg, 1981). One is Paivio's model of bilingual memory 
(Paivio, 1986; Paivio \& Desrochers, 1980; Paivio \& Lambert, 1981). It contends that the representations of words are stored in memory modules that are separate and independent but also interconnected, primarily across translation equivalents. Representations in the separate verbal systems may also be connected to image representations in a separate image store, in which sensory/perceptual information is encoded. Representations of translationequivalent words may be connected to the same image representation, providing a second pathway between the two verbal systems.

Other researchers have found evidence of a general separate store model but not of the dual-coding assumption of a special image store, and therefore limit their discussion to a more general but interconnected model (Grainger \& Beauvillain, 1988; Kirsner, Smith, Lockhart, King, \& Jain, 1984; Meyer \& Ruddy, 1974).

A general separate but interconnected model can account for the research cited above. Cross-language Stroop effects, primary associates, and recall organization can be attributed to the interconnections between specific language systems. Transfer of learning and repetition effects on recall with translation associates can be attributed to the cross-language connections between translation equivalents.

The second model is the three-code, or hierarchic, model of bilingual memory (Potter, So, Von Eckardt, \& Feldman, 1984; Snodgrass, 1984), which is based on the more general three-code model of memory (Potter, 1979; Potter, Kroll, Yachzel, Carpenter, \& Sherman, 1986). In this model of bilingualism, the mind contains three different codes for representations of words: two separate codes for the surface forms of words expressed in the two languages, and a third code for the shared representations of the semantic meanings of the words. Thus, surface forms of words in different languages have separate representations and are stored in separate systems while the semantic meanings of all words are stored as amodal propositional nodes (Anderson \& Bower, 1973) in a shared semantic network (Collins \& Loftus, 1975).

This model can explain greater within- than betweenlanguage Stroop effects, greater within- than betweenlanguage primary associate production, and higher performance within than between languages on recall organization as the effects of the separate verbal stores at the lexical level. The reduction in proactive interference in recall with language change in a list, as well as the robust effect of subjects' ability to recall the language of presentation of stimuli, can be also attributed to processes specific to the lexical level of processing.

An important paradigm that is used to test the separate and hierarchic models is the primed lexical decision task (LDT) (Meyer \& Schvaneveldt, 1971). In monolingual experiments, a target preceded by a related word (CATDOG) is judged to be a real word faster than a target preceded by an unrelated word (TABLE-DOG). This priming effect is assumed to be due to a process such as automatic activation (Posner \& Snyder, 1975), transfer (Kolers \& Roediger, 1984), or activation of a combined cue (Rat- cliff \& McKoon, 1988). (For a review of the literature on the monolingual primed LDT, see Neely, 1990.)

In bilingual experiments, the prime is in one language and the target in another (CHAT-DOG). The shared-store model contends that the effect of the prime on the target occurs in the amodal, shared propositional store, causing priming to occur across languages. The general separate, interconnected model assumes that the links between the separate language-specific memory systems are weaker than the links within memory systems, so that the model predicts either no priming across languages or, at the least, priming that is significantly less than that occurring within languages.

Most bilingual primed LDT experiments have produced cross-language priming (Chen \& $\mathrm{Ng}, 1989$; Jin, 1990; Meyer \& Ruddy, 1974; Schwanenflugel \& Rey, 1986). However, cross-language priming effects have disappeared when the proportion of related pairs was small (.25) and the subjects highly proficient in L2 (Grainger $\&$ Beauvillain, 1988), and also when (noncognate) primes were masked (de Groot \& Nas, 1991). The results of these two experiments suggest that the cross-language priming effects found in the other experiments may not reflect a shared conceptual store but rather a strategy of predicting the target from the prime (Becker, 1979, 1980) or of translating the prime (de Groot \& Nas, 1991). If strategy was involved in these studies, the results do not necessarily inform us about representation, because strategy, a controlled process, is not assumed to reflect the basic organization of representations in memory (Neely, 1977, 1990; Posner \& Snyder, 1975).

Priming may also reflect a meaning-integration process that occurs after access of the target and affects the decision stage of the task. Such a model has been proposed for both monolingual (de Groot, 1984) and bilingual (de Groot \& Nas, 1991) priming.

At issue is whether cross-language priming reflects the organization of representations in memory or whether it reflects strategy. Experiment 1 was designed to test this question. We capitalized on the demonstration in monolingual experiments that a high proportion of related pairs encourages subjects to use strategy (de Groot, 1984; den Heyer, Briand, \& Dannenberg, 1983; Neely, 1977; Tweedy \& Lapinski, 1981; Tweedy, Lapinski, \& Schvaneveldt, 1977). Therefore, only $25 \%$ of the pairs were related, a percentage which was lower than that used in all the experiments mentioned above, except that of Grainger and Beauvillain (1988, Experiment 2), who did not find crosslanguage priming.

The percentage (proportion) of related pairs is known to have other effects in monolingual experiments that may affect the bilingual case. For example, proportion effects increase with the length of the stimulus onset asynchrony (SOA)-the time between the onset of the prime and the onset of the target (de Groot, 1984; den Heyer et al., 1983; Neely, 1977). These effects are assumed to occur because strategy depends on time-consuming, controlled, conscious processing (Neely, 1977; Posner \& Snyder, 
1975). To discourage strategies, we used a brief SOA of $250 \mathrm{msec}$ in one condition. We also included a 2,000msec condition to index the priming found with the low proportions of related pairs and longer SOAs.

Neutral primes have been used to determine whether priming effects are primarily automatic or controlled (Balota, 1983; Neely, 1977). If facilitation occurs (i.e., if responses to related targets are faster than responses to neutrally primed targets), this presumably indicates that some of the overall priming is due to automatic processes. However, if inhibition occurs (if responses to unrelated targets are slower than responses to neutrally primed targets), then the overall priming effect is assumed to be due to controlled, conscious processing and, perhaps, to strategy use. We included neutral primes in our design to measure the contribution of automatic and controlled processing to the priming effect.

To determine if subjects were processing the primes in both language-order conditions, on a few trials we included a task in which the subjects were required to repeat the name of the prime after responding to the target.

In the overall design of the experiment, SOA (250 and $2,000 \mathrm{msec}$ ) was a between-subjects factor; the two withinsubjects factors were relatedness (related, unrelated, and neutral) and language order of the pair (Chinese primeEnglish target and English prime-Chinese target).

\section{EXPERIMENT 1}

\section{Method}

Subjects. Forty native Chinese-speaking, Chinese-English bilingual subjects participated in the experiment. They were all staff members at Hong Kong University, and all had studied English since primary school. The subjects were screened by using standardized tests in English (Sack \& Yourman, 1975) and comparable tests designed and standardized in Chinese by the experimenters (Keatley, 1987). The tests were made up of three passages of informational text which the subjects read silently. Each passage was followed by 10 comprehension questions. Average word-per-minute reading speeds were calculated for each subject as were average comprehension scores. The subjects who participated in the experiment had normal to excellent reading comprehension ( $70 \%$ or higher average scores on the comprehension tests) and read in both English and Chinese as fast as or faster than average native speaker-readers with university educations.

Stimuli. Fifty-four cross-language prime-target pairs were developed (Keatley, 1987). The primes and targets within each pair were primary associates in both English and Chinese and translations of each other. The Chinese stimuli were single character pairs in which both primes and targets could stand alone as single lexical units-unbound morphemes-and in which the prime and the target had no, or minimal, visual redundancy. The English words were 3-8 letters in length, with a mean of 4.2 letters. The Chinese characters varied in complexity from 2 to 16 strokes. The mean associative strength of the Chinese within-language pairs was 42.2; of the English pairs, it was 36.0.

Within each list, the experimental pairs were used to form pairs in the related, unrelated, and neutral conditions. Neutral pairs were formed by using XXXX as the neutral primes. Nine filler pairs were constructed in each language-order condition, as were 32 false-target pairs. The filler pairs were always unrelated, but one quarter of the false-target pairs were presented as related (the word on which the false target was based was related to the prime).
Chinese false targets were developed by changing one character component of a real character to another component, or by adding, omitting, or reorienting a single stroke. English false targets were formed by changing one letter in each word so that the resulting nonwords were pronounceable and orthographically regular.

The stimuli were presented on slides. The characters were written in their full form (not abbreviated) by hand and photographed The stimuli are listed in Appendix A.

List construction. The stimuli in the two language-order conditions were blocked. Twenty lists were constructed, with relatedness and language order counterbalanced across the lists. One subject in each SOA condition saw each of the lists. Each target concept was seen only once by each subject.

Apparatus. A three-field tachistoscope was constructed by back projecting three Kodak Ectographic Model B-2AR slide projectors so that the images overlapped. Each projector had a Gerbrands G1166 shutter controlled by an Apple II computer.

Procedure. Each subject performed the primed LDT in an individual session of about $1 \mathrm{~h}$. The subjects were given instructions in a combination of English and Chinese. Twenty-four practice trials occurred before each half of the experiment. The procedure on each trial was as follows: (1) The experimenter said "One, two, three ..." in the language of the target. (2) The fixation mark, an asterisk, appeared in the center of the screen for $450 \mathrm{msec}$. (3) It was replaced by the prime stimulus, which was visible for $200 \mathrm{msec}$ (the 250-msec SOA condition) or 1,950 msec (the 2,000-msec SOA condition). (4) The prime was followed by a 50-msec blank field. (5) The target appeared on the screen, and at the same time the chronometer was activated. (6) The subject responded by pushing one of the buttons, which stopped the chronometer. (7) The experimenter read the reaction time to the subject and gave feedback on the correctness of the response.

Six times within each half of the experiment the subject was asked to repeat the prime after the reaction time had been reported. There was a 5-min mandatory rest between the two blocks of trials.

\section{Results}

Only responses to the 54 real-word targets from the experimental list were analyzed. Scores over $1,400 \mathrm{msec}$ and scores associated with subject or mechanical errors were excluded from the analyses. The total scores excluded constituted $5.7 \%$ of the total experimental trials. The errors were roughly evenly distributed across the experiment and across the various conditions.

Analyses were carried out across subjects, but not across items because the data were not available. Because all the items served in the different conditions for all the subjects, however, it can be assumed that the error variance associated with the items was included in the interactions between subjects and the various conditions. All results reported as significant have an alpha level of at least .05 .

The data appear in Table 1. An analysis of variance (ANOVA) was carried out with SOA (250 msec, 2,000 $\mathrm{msec}$ ) as a between-subjects factor, and relatedness (related, unrelated, neutral) and language order (Chinese prime-English target, English prime-Chinese target) as within-subjects factors. The results of the full ANOVA yielded no significant main effects and no interactions. However, because of the specificity of the hypotheses under test, planned comparisons were conducted to test whether overall priming, facilitation, or inhibition occurred in any particular conditions. 
Table 1

Experiment 1: Mean Reaction Time Scores (in Milliseconds) With Errors, and Mean Priming, Facilitation, and Inhibition Effects in Each of the Two LanguageOrder Conditions Across Long and Short SOA Conditions (in Milliseconds)

\begin{tabular}{|c|c|c|c|c|c|c|c|c|c|}
\hline \multirow[b]{3}{*}{ SOA } & \multicolumn{6}{|c|}{ Target } & & & \\
\hline & \multicolumn{2}{|c|}{ Related } & \multicolumn{2}{|c|}{ Unrelated } & \multicolumn{2}{|c|}{ Neutral } & \multicolumn{3}{|c|}{ Effect } \\
\hline & $M$ & $E$ & $M$ & $E$ & $M$ & $E$ & Priming & Facilitation & Inhibition \\
\hline \multicolumn{10}{|c|}{ English Prime-Chinese Target } \\
\hline 250 & 597 & 2.7 & 592 & 2.7 & 596 & 4.4 & -5 & -1 & -4 \\
\hline 2,000 & 624 & 4.4 & 610 & 3.8 & 646 & 5.5 & -14 & 22 & -36 \\
\hline \multicolumn{10}{|c|}{ Chinese Prime-English Target } \\
\hline 250 & 598 & 5.5 & 636 & 3.3 & 608 & 6.6 & 38 & 10 & 28 \\
\hline 2,000 & 598 & 5.5 & 612 & 4.4 & 639 & 9.4 & 14 & 41 & -27 \\
\hline
\end{tabular}

The planned comparisons revealed that the only significant priming effect, $38 \mathrm{msec}$, occurred in the Chinese prime-English target condition with a short SOA $[t(76)=$ $\left.2.467, M S_{\mathrm{e}}=2,374, p<.01\right]$. Significant inhibition, $28 \mathrm{msec}$, also occurred only in this condition $[t(76)=$ $1.818, p<.05]$. Facilitation, $41 \mathrm{msec}$, occurred only in the Chinese-English long SOA condition $[t(76)=2.662$, $p<.01]$. The 14-msec priming effect in this condition, however, was nonsignificant $[t(76)=0.91]$. There was also an unexpected 27-msec advantage for unrelated over neutral targets in the Chinese-English long SOA condition.

Neutral-primed targets were responded to, in, on the average, $622 \mathrm{msec}$, which was slower than mean responses to related targets, $604 \mathrm{msec}$, and slower than responses to unrelated targets, $613 \mathrm{msec}$. Although these differences were not significant, this pattern was unexpected, since most studies report that neutral-primed targets are responded to faster than unrelated targets and slower than related targets (Neely, 1990). The difference between the results of this experiment and others may have been related to the memory task, in which subjects were asked to recall the prime after responding to the target. Since the crucial question of the experiment was whether priming occurs under the different conditions, another ANOVA was carried out on related and unrelated target scores to test the significance of priming effects alone. There were no significant main effects. A significant interaction occurred between language order and relatedness $[F(1,38)=$ $6.43, M S_{\mathrm{e}}=12,443.26, p<.015$ ]. Specific comparisons confirmed that significant priming occurred only in the Chinese-English short SOA condition $[t(38)=2.733$, $\left.M S_{\mathrm{e}}=1,934.92, p<.01\right]$. There were no other interactions.

In all but two instances, subjects were able to recall the name of the prime when asked, after having made a lexical decision to the target.

\section{Discussion}

The most important result of the analysis was the finding that priming occurred only when primes were in Chinese and targets in English in the short SOA condition. The fact that significant inhibition accompanied the priming effect might be evidence for a controlled process. However, it is difficult to interpret the facilitation and inhibition data, because the neutral primes produced results that were unexpected. The data pattern suggests that the subjects may have been rehearsing the prime word, especially in the long SOA condition, in order to recall it after the trial. This may have led to a general activation that did not occur when the prime was not a word.

The fact that the priming occurred in the short SOA condition and not in the long SOA condition suggests that the effect did not require a long time to be effective and therefore was not due to the use of strategies (Neely, 1977; Posner \& Snyder, 1975). The priming that did occur in the experiment was asymmetrical; that is, it occurred in one language direction and not in the other. One explanation for this is that because the subjects' first language was Chinese, this language was processed faster than their second language, English. Target language, however, did not produce a significant effect either in the full analysis $[F(2,76)=0.10]$ or in the restricted analysis $[F(1,38)=$ $0.11]$. The subjects were able to identify targets in English and Chinese at the same rate: $615 \mathrm{msec}$ for English and $611 \mathrm{msec}$ for Chinese targets. Neutrally primed English targets were responded to with a mean latency of $624 \mathrm{msec}$; neutrally primed Chinese targets, with a mean latency of $621 \mathrm{msec}$.

Because the asymmetry in priming could not be attributed to an imbalance in language proficiency on the LDT task, the results of Experiment 1 present a dissociation between priming effects and reaction time on the LDT.

One explanation for the dissociation may be that whereas reaction times on the LDT reflect the fact that a representation is available to consciousness on the basis of its threshold and activation level (Posner, 1978), crosslanguage priming reflects the strength of cross-language connections between separate language systems. While the threshholds and activation levels of the representations of the words in Chinese and English must have been about the same in Experiment 1, the cross-language effects from $\mathrm{L} 1$ to $\mathrm{L} 2$ were stronger than those from $\mathrm{L} 2$ to $\mathrm{L} 1$.

Stronger cross-language effects from $\mathrm{L} 1$ to $\mathrm{L} 2$ may be attributable to richer and stronger representations in the 
L1 memory system, to stronger connections between representations within the $\mathrm{L} 1$ memory system, and also to stronger connections from L1 representations across memory systems to representations in other memory systems. This idea is discussed further in the General Discussion.

Another possible explanation for the asymmetry found in Experiment 1 is that it resulted from the use of single Chinese characters. Chen and $\mathrm{Ng}$ (1989) used two-character Chinese lexical units and English words, and found significant cross-language priming in both language-order conditions.

To test whether the asymmetrical priming effect was specific to the language combination of Experiment 1, a second experiment was carried out with Dutch-French bilinguals.

\section{EXPERIMENT 2}

This experiment was conducted in Brussels, Belgium. It tested only the short SOA condition, because the questions under test were about automatic processes, not strategy. The short SOA was reduced from $250 \mathrm{msec}$ in Experiment 1 to $200 \mathrm{msec}$ in this experiment, and feedback was deleted. Both changes were made to further discourage strategic processing. Furthermore, because the subjects in Experiment 1 were able to recall L2 primes, the prime recall test was deleted. Within- as well as between-language conditions were included in Experiment 2 , because they yield information about the bilinguals' memory organization and functioning.

\section{Method}

Subjects. The 32 subjects were native Dutch speakers who had studied French from age 7 years. They were screened as were the subjects in Experiment 1, with reading tests in French and Dutch which were translations of the English tests used in Experiment 1. Speed and comprehension norms for the French and Dutch tests were established by using native French- and Dutch-speaking university students.

Stimuli. Ninety-six cross-language primary associate pairs were developed as the stimuli of Experiment 1 . The words were of middle to high frequency in French (Savard \& Richards, 1970) and in Dutch (Uit den Boogaart, 1975). The mean length of the French targets was 5.27 letters; that of the Dutch targets, 5.05 letters. The mean association strength of the French pairs was 40.13 , and that of the Dutch pairs, 40.10 .

Unrelated pairs were formed, as in Experiment 1. Ninety-six unrelated filler pairs were developed to provide the subjects with a context within which only a .25 proportion of the real-word target pairs, .125 of all prime-target pairs, were related.
One half of the stimuli were false-target pairs, constructed by replacing one letter in a real-target word in the appropriate language. False-target pairs were always presented as unrelated.

The stimuli are listed in Appendix B.

List construction. Each subject saw 384 different prime-target pairs broken into four different language-order blocks of 96 pairs. The order of the presentation of the blocks was determined by a balanced square. Relatedness of the targets (related, unrelated) was counterbalanced across subjects

Procedure and Apparatus. Each subject was tested individually, using a Primavera computer with a CRT and a separate keyboard. Before each language-order block, the subjects were given 24 practice trials. They initiated groups of 24 trials themselves. On each trial, a central fixation stimulus, a small cross, appeared in the screen center for $300 \mathrm{msec}$, followed by a 50 -msec blank screen. The prime word appeared in the same place and remained for $150 \mathrm{msec}$, followed by a blank screen for $50 \mathrm{msec}$. The target then appeared just under the space where the prime had been. It remained on the screen until the subject responded. There was a $1,500-\mathrm{msec}$ interstimulus interval between the subject's response and the onset of the next trial. A rest of at least 3 min occurred between the four language-order blocks.

\section{Results}

Responses to the 96 cross-language real-target pairs were included in the analysis. Scores were treated as in Experiment 1. Errors accounted for $.07 \%$ of the responses. All results reported have a significance level of at least $p<.05$ by subjects and by items unless otherwise indicated.

The subjects' mean scores and errors are displayed in Table 2. The mean scores were subjected to an ANOVA. Language of the target (French, Dutch), relatedness (related, unrelated), and language mix (same-language pair, different-language pair) were within-subjects factors.

Relatedness produced a significant overall main effect by subjects and by items $\left[F_{\mathrm{s}}(1,31)=60.82, M S_{\mathrm{e}}=\right.$ $\left.933.84 ; F_{\mathrm{i}}(1,95)=17.57, M S_{\mathrm{e}}=189,416.12\right]$, indicating that the overall $29-\mathrm{msec}$ faster response to related targets was significant. Target language produced a strong main effect $\left[F_{\mathrm{s}}(1,31)=197.13, M S_{\mathrm{e}}=4,871.25\right.$; $\left.F_{\mathrm{i}}(1,95)=224.35, M S_{\mathrm{e}}=2,751,915.0\right]$, with a 121 msec advantage for Dutch targets. The effect of language mix was also significant $\left[F_{\mathrm{s}}(1,31)=12.02, M S_{\mathrm{e}}=\right.$ $\left.4,270.22 ; F_{\mathrm{i}}(1,95)=17.73, M S_{\mathrm{e}}=98,199.31\right]$, with a mean $27-\mathrm{msec}$ faster response to targets with samelanguage primes than to targets with different-language primes. The interaction between target language and relatedness was significant in the items analysis $\left[F_{i}(1,95)=\right.$ $\left.5.11, M S_{\mathrm{e}}=20,666.59\right]$, but not in the analysis by subjects $\left[F_{\mathrm{s}}(1,31)=3.62, M S_{\mathrm{e}}=5,540.94, p=.066\right]$.

Table 2

Experiment 2: Mean Reaction Time (in Milliseconds), Percentage of Errors (PE), and Priming Effects in Each of the Language-Order and Relatedness Conditions

\begin{tabular}{|c|c|c|c|c|c|c|c|c|c|}
\hline \multirow[b]{3}{*}{ Target } & \multicolumn{8}{|c|}{ Language Order } & \multirow[b]{3}{*}{$M$} \\
\hline & \multicolumn{2}{|c|}{ Dutch-Dutch } & \multicolumn{2}{|c|}{ French-Dutch } & \multicolumn{2}{|c|}{ French-French } & \multicolumn{2}{|c|}{ Dutch-French } & \\
\hline & $M$ & $P E$ & $M$ & $P E$ & $M$ & $P E$ & $M$ & $P E$ & \\
\hline Related & 455 & .01 & 491 & .02 & 573 & .04 & 597 & .03 & 529 \\
\hline Unrelated & 485 & .02 & 502 & .03 & 607 & .06 & 639 & .05 & 558 \\
\hline Priming & 30 & & 11 & & 34 & & 42 & & \\
\hline
\end{tabular}


Table 3

Summary of Cross-Language Primed Lexical Decision

Task Experiments With Primary Associate Stimuli

\begin{tabular}{|c|c|c|c|c|c|c|}
\hline \multirow[b]{2}{*}{ Experiment } & \multirow{2}{*}{$\begin{array}{l}\text { Proportion } \\
\text { Related* }\end{array}$} & \multirow[b]{2}{*}{ SOA } & \multirow{2}{*}{$\begin{array}{c}\text { Mean } \\
\text { RT } \dagger\end{array}$} & \multirow{2}{*}{$\begin{array}{c}\text { Mean RT } \\
\mathrm{L} 1-\mathrm{L} 2\end{array}$} & \multicolumn{2}{|c|}{ Priming } \\
\hline & & & & & L1-L2 & L2-L1 \\
\hline Altarriba (1991) & .33 & 200 & 679 & 164 & 68 & 27 \\
\hline Chen \& Ng & & & & & & \\
\hline (1989, Experiment 1)‡ & .66 & 300 & 995 & 160 & 130 & 50 \\
\hline $\begin{array}{l}\text { Grainger \& Beauvillain } \\
\text { (1988, Experiment 2) }\end{array}$ & .25 & 150 & 541 & 23 & 7 & 12 \\
\hline Jin $(1990)$ & .66 & 150 & 710 & 85 & 91 & 15 \\
\hline Kirsner et al. & & & & & 54 & 48 \\
\hline Meyer \& Ruddy (1974) & .33 & $0 \S$ & $1,130 \|$ & 47 & $\begin{array}{r}54 \\
143\end{array}$ & $\begin{array}{r}40 \\
116\end{array}$ \\
\hline $\begin{array}{l}\text { Schwanenflugel \& Rey } \\
(1986, \text { Experiment } 2)\end{array}$ & 1.0 & 100 & 751 & 78 & 29 & 15 \\
\hline
\end{tabular}

Note-SOA, RT, and priming are given in milliseconds. *Proportions include associates and translation equivalents. †Mean RTs are only roughly comparable, since designs vary. †Values are estimated from a graph. §Simultaneous presentation. IThis value is estimated from graphics.

Planned comparisons indicated that significant priming occurred in all conditions except the French-Dutch languageorder condition: Priming in the Dutch-Dutch condition was significant $\left[t(1,31)=2.608, M S_{\mathrm{e}}=2,122.58, p<\right.$ $.005]$, as it was in the French-French condition $[t(1,31)=$ $2.957, p<.005]$ and the Dutch-French condition $[t(1,31)=3.652, p<.005]$. Only the 11 -msec overall priming in the French-Dutch condition did not reach significance $[t(1,31)=0.956]$.

\section{Discussion}

Overall, the results of Experiment 2 confirmed the results of Experiment 1. Asymmetry occurred in crosslanguage priming, given a relatively short SOA and small proportion of related pairs. Indeed, an analysis of the existing cross-language priming experiments suggests that asymmetry has been reported with regularity in the literature. Table 3 lists the cross-language primed LDT experiments that were reported above.

In all the experiments (except that of Grainger \& Beauvillain, 1988), more priming occurred when the prime was in the first (or dominant) language of the subjects (L1) and the target in their second language (L2), than when the prime and target were in the reverse language order, L2-L1 (Altarriba, 1991; Chen \& Ng, Experiment 1, 1989; Jin, 1990; Kirsner et al., 1984; Meyer \& Ruddy, 1974; Schwanenflugel \& Rey, 1986).

As shown in the other columns of Table 3, the experiments vary so greatly in their designs that it is not possible to determine from this information the factors associated with asymmetry. It can be seen, however, that asymmetry appears to be a continuum, rather than an allor-none phenomenon.

In another series of experiments, we studied the effects of subject stress on cross-language priming. We found that cross-language priming disappeared, whereas withinlanguage priming persevered if subjects were required to respond at a fixed fast rate (Keatley \& de Gelder, 1992). We concluded that cross-language priming is caused by a postlexical access meaning-integration process that occurs automatically in normal reading, but that can be detached and removed from the normal reading sequence through conscious strategy by subjects whenever they find that the meaning integration interferes with response speed. De Groot and Nas (1991) came to a similar conclusion earlier when they found that if they masked the prime in an LDT experiment, within-language priming persisted with primary associates, but not cross-language priming (unless the targets were cognates or translation equivalents).

If the preceding hypothesis is correct, then more symmetrical cross-language priming may reflect the normal meaning-integration process, whereas asymmetry may reflect differences in the strengths of cross-language connections between language-specific memory systems that become more apparent when subjects attempt to discontinue the meaning-integration processing.

Several of the experiments cited above, however, have included translation-equivalent pairs in their stimulus lists as well as primary associates (Altarriba, 1992; Chen \& $\mathrm{Ng}, 1989$; Jin, 1990). Similar patterns of cross-language priming were found, as well as asymmetry with translations. Because the two kinds of stimuli were presented together, however, it is possible that the presence of primary associates influenced the subjects' perception of translation equivalents, or vice versa. We conducted Experiment 3 in the same sessions as we did Experiment 2, just after Experiment 2. The subjects were unaware that these were separate experiments because the procedures were similar, the difference being that the crucial pairs in Experiment 3 were translation equivalents. Because we found no significant priming in Experiment 1 in the L2-L1 condition with primary associates (and most other experiments resulted in some priming in this condition), 
we predicted that, if no priming occurred in that condition in Experiment 2 with primary associates, priming would also not occur with translation equivalents.

\section{EXPERIMENT 3}

\section{Method}

Subjects. The subjects were those who participated in Experiment 2.

Stimuli. Forty-eight cross-language translation-equivalent pairs were developed which could be presented either with the French translation as the prime (CHEVAL-PAARD) or the Dutch translation as the prime (PAARD-CHEVAL). The words were 3-8 letters long and of medium frequency (Savard and Richards, 1970; Uit den Boogaart, 1975). Half the words named concrete objects and half named abstract concepts. Unrelated pairs, filler pairs, and false-target pairs were created by using the same methods as in Experiment 2 . There were 24 practice pairs before each of the two language-order blocks. The stimuli are listed in Appendix $C$.

List construction and counterbalancing procedures were the same as in Experiment 2. There were two language-order blocks, each including 12 experimental related pairs and 12 experimental unrelated pairs, 24 unrelated filler pairs, and $\mathbf{4 8}$ false-target pairs.

\section{Results}

As in Experiment 2, scores over $1,400 \mathrm{msec}$ or associated with errors were excluded from the analyses. This included .06 of the data. All results reported as significant have an alpha level of at least .05. Mean scores and error rates are displayed in Table 4.

An ANOVA was carried out on the data to test the two levels of relatedness (translation, unrelated) and target language (French, Dutch). Relatedness produced a significant main effect $\left[F_{\mathrm{s}}(1,31)=34.83, M S_{\mathrm{e}}=2,258.40\right.$; $\left.F_{\mathrm{i}}(1,47)=18.83, M S_{\mathrm{e}}=7,194.69\right]$, indicating that the 50 -msec faster response to translation-equivalent pairs was significant. Language of the target also produced a main effect $\left[F_{\mathrm{s}}(1,31)=125.61, M S_{\mathrm{e}}=3,382.79 ; F_{\mathrm{i}}(1,47)=\right.$ $160.11, M S_{\mathrm{e}}=3,964.09$ ], with a 115 -msec advantage for Dutch targets. Language of the target and equivalence also produced an interaction $\left[F_{\mathrm{s}}(1,31)=6.77, M S_{\mathrm{e}}=\right.$ $\left.1,213.23 ; F_{\mathrm{i}}(1,47)=7.03, M S_{\mathrm{e}}=2,559.38\right]$, demonstrating that the 66-msec priming in the Dutch primeFrench target condition was significantly greater than the 34-msec priming in the French prime-Dutch target condition.

\section{Discussion}

In contrast to what was found in Experiment 2, significant cross-language priming effects appeared across trans-

Table 4

Experiment 3: Mean Reaction Times, Error Rates $(P E)$, and Priming in Translation-Equivalent Priming

\begin{tabular}{|c|c|c|c|c|c|}
\hline \multirow[b]{3}{*}{ Target } & \multicolumn{4}{|c|}{ Language Order } & \multirow[b]{3}{*}{$M$} \\
\hline & \multicolumn{2}{|c|}{ French-Dutch } & \multicolumn{2}{|c|}{ Dutch-French } & \\
\hline & $M$ & $P E$ & $M$ & $P E$ & \\
\hline $\begin{array}{l}\text { Related } \\
\text { Unrelated }\end{array}$ & $\begin{array}{l}477 \\
511\end{array}$ & $\begin{array}{l}.01 \\
.02\end{array}$ & $\begin{array}{l}576 \\
642\end{array}$ & $\begin{array}{l}.08 \\
.13\end{array}$ & $\begin{array}{l}527 \\
577\end{array}$ \\
\hline Priming & 34 & & 66 & & \\
\hline
\end{tabular}

lation equivalents in both language-order conditions. Significantly more priming occurred in the L1-L2 condition.

This result suggests that the L1-L2 links are stronger between translation equivalents than between primary associates. However, since translation-equivalent priming is also significantly greater in L1-L2 than in L2-L1, this priming is also asymmetrical. Overall, the results support the hypothesis that the $L 1$ representations have stronger, richer connections within and across specific memory systems and thus produce a stronger priming context than do the $L 2$ representations.

\section{GENERAL DISCUSSION}

Three experiments were conducted to test the organization of bilingual memory. The first produced a dissociation between priming effects and LDT reaction time when bilingual subjects, who responded at the same rate on the LDT to stimuli in Chinese and English, produced significant priming in the Chinese-English (L1-L2) condition but not in the English-Chinese (L2-L1) condition. The second experiment demonstrated that this asymmetry could also occur with two alphabetic languages. It was proposed that asymmetry in priming might be due to a stronger context effect provided by the $\mathrm{L} 1$ representations. The third experiment demonstrated that priming of translation equivalents occurs in the L2-L1 languageorder condition as well as in L1-L2, suggesting direct connections between these representations. Furthermore, asymmetry also occurred in priming with translationequivalent words, indicating that the $\mathrm{Ll}$ primes provide a stronger context than do the L2 primes.

Although asymmetry in priming has occurred in a number of experiments (see Table 3), Experiment 1 of this series is the only experiment that has produced equal lexical decision times for stimuli in the two language-order conditions and also asymmetrical priming, thus affirming that the asymmetry cannot be attributed solely to differences in access or decision times across the languages on the LDT.

The classic hierarchical model cannot account for this asymmetry, because it assumes that the semantic representations of translation-equivalent words are one and the same and that they therefore must produce identical patterns of semantic priming as long as lexical access time remains equivalent.

This dissociation between LDT reaction time and priming argues for a separate-store model of bilingual memory. However, it is clear that a completely separate store could not account for the fact that, in some conditions such as translation-equivalent stimuli, there are close, strong links across representations of words expressed in different languages.

We propose a tentative, separate but interconnected model of bilingual memory which borrows some assumptions from Paivio's dual-coding model (Paivio, 1986; Paivio, Clark, \& Lambert, 1988; Paivio \& Desrochers, 1980). Our model assumes that single representations 
of words contain, in one entity, all information about the words, lexical and conceptual. These representations reflect the perceptual-sensory system and the specific symbol system of their encoding. The meaning of a representation within a language-specific memory store is determined by its position in a network of interrelated representations, such as that described in semantic network models (Collins \& Loftus, 1975). Representations of words may also have direct connections to representations in other symbol-system-specific modules, perhaps as a result of pairing the two stimuli. For instance, translation equivalents may have direct connections due to experiences in which the two stimuli are paired and identified as equivalents. One-to-one connections across languagespecific systems do not extend beyond the connected representations; although priming effects occur across connections between translation equivalents, they do not extend to associates of translation equivalents in cross-language associate priming.

Within-language connections and cross-language connections are different: the former are part of a tightly interrelated network, the latter are more one to one. The former are more likely to be active in representing the meaning of a word, because they are part of the network when the subject processes words in that language.

This model suggests that within-language associative priming is the result of transfer occurring across related representations stored together in a network of interrelated representations. Cross-language translation-equivalent priming is attributed to one-to-one connections between the representations across memory systems. Cross-language associative priming is attributed to meaning-integration processes which are a normal, but not integral, part of the reading process, and which can be dissociated from the reading process (de Groot \& Nas, 1991; Keatley \& de Gelder, 1992). Asymmetry in cross-language associate and translation-equivalent priming is due to the stronger connections from the L1 language memory system, which, in the case of cross-language associate priming, may be exploited by the meaning-integration process.

Presumably, even in very balanced bilinguals, $\mathrm{L} 1$ representations may be richer and stronger than those of L2 because they are based on multiple encodings of the word in various $L 1$ verbal contexts and on many encodings of the word in various cross-model contexts, such as the naming of an object. L2 acquisition may produce representations that are less highly connected both within and across memory systems, but which still refer to the same external objects.

A general model of transfer of information across specific memory systems has been developed in the motor skill literature and has been adapted to explain transfer of skill in verbal tasks by the transfer-appropriate models of memory (Durgunoglu \& Roediger, 1987; Kolers \& Roediger, 1984). In general, the model holds that while representation is symbol-system specific, information can be transferred across specific memory systems. Transfer, however, does not produce exact replicas of repre- sentations in the two systems. The transferred information is incomplete; it is modified by the structure of the specific symbol system and by its place in a new network of relations between representations.

This model can be applied to L2 representation. During L2 acquisition, the information about the meaning of a new word may be acquired and stored, at least partially, by copying or transferring the information from the L1 language system to the new L2 language system. Whereas the $L 1$ representation would include multiple L1-specific encodings of experiences of the word, including rich connections both internally and across memory systems, the L2 representation would initially include only a portion of this information, modified by the different (and less elaborate) linguistic network of the L2 store and, in time, by the different experiences of the student in $\mathrm{L} 2$ contexts. Overall $\mathrm{L} 1$ representations would have generally richer, stronger connections across memory systems than would L2 representations, even in proficient bilinguals.

Kroll and Stewart (1990) have developed a revised hierarchic model that also accounts for asymmetry in crosslanguage associative priming. This model assumes that two routes exist for transfer in priming. Transfer from L1 to L2 is held to be primarily conceptual, with the transfer passing through a shared conceptual store that is the locus of the associative priming effect; transfer from $\mathrm{L} 2$ to $\mathrm{L} 1$ is primarily lexical and hence produces less priming. $L 1$ lexical representations are closer to the shared conceptual store.

Both our model and the revised hierarchic model predict that $L 1$ representations will have stronger conceptual effects than will L2 representations. In our model, this is because the $\mathrm{L} 1$ representations are stronger overall and more richly connected within the L1 memory system and across different specific memory systems. In the revised hierarchic model, $\mathrm{L} 1$ representations have stronger links to the shared conceptual store. The main difference in the predictions of the two models of asymmetry is that our separate model attributes asymmetry to the overall different strengths of the connections from the $\mathrm{L} 1$ and $\mathrm{L} 2$ language systems, whereas the hierarchic model attributes it to different kinds of connections, conceptual or lexical, when the language order is L1-L2 or L2-L1.

Kroll and her colleagues have demonstrated that bilinguals read faster in L1, but translate faster from $\mathrm{L} 2$ to L1 than from L1 to L2 (Kroll \& Curley, 1988; Kroll \& Stewart, 1990), and these results have been confirmed by other studies (Sanchez-Casas, Davis, \& Garcia-Albea, 1992). Kroll and her colleagues have attributed this to the different pathways: they suggest that L2-L1 translation is shorter because the lexical pathway involves only two lexical stores and not the third, conceptual store, which is activated in the L1-L2 condition. However, we interpret the data as demonstrating once again that the L1 representations are more accessible and have stronger connections in the general memory system. They produce more priming and are accessed faster overall than the L2 representations. 
In a translation-production experiment (Keatley \& de Gelder, 1992), we found that subjects' errors tend to be semantic (the subject says "river" when the correct translation is "lake") in both the L1-L2 and L2-L1 conditions. If $\mathrm{L} 2-\mathrm{L} 1$ translation production depended primarily on a lexical route, we would expect subjects to make lexical errors (the subject says "like" when the correct translation is "lake"). This did not occur. We concluded that the differences of translation speed in the L1-L2 and L2-L1 conditions are differences of overall accessibility of $L 1$ and $L 2$ representations, not differences in the pathways from stimulus to translation in the two languageorder conditions.

There is evidence of interference from semantically categorized lists with more proficient bilinguals in the L1-L 2 condition on a translation-production task, but not of interference in the L2-L1 condition (Kroll \& Stewart, 1990). This supports the idea that there is a conceptual pathway in the L1-L2 condition that does not occur in the L2-L1 condition. It is possible, however, that this phenomenon may occur because of the overall stronger connections within a separate $\mathrm{L} 1$ memory system - an interpretation more compatible with a separate-model approach.

Asymmetry in cross-language priming is a phenomenon that needs to be explained by models of the crosslanguage-primed LDT. We have outlined a tentative separate-interconnected model that accounts for this asymmetry. The revised hierarchical model also accounts for asymmetry, but on the basis of a shared-store model. Although the research in this paper generally lends more support to the separate-store model, more research is needed to provide a clear account of cross-languagepriming asymmetry.

\section{REFERENCES}

AltaRRIBA, J. (1991). Is there automatic semantic priming across a bilingual's two languages? Paper presented at the meeting of the American Psychological Society, Washington, DC.

AltARRIBA, J. (1992). The representation of translation equivalents in bilingual memory. In R. Harris (Ed.), Cognitive processing in bilinguals (pp. 157-174). Amsterdam: Elsevier.

ANDERSON, J. R., Bower, G. H. (1973). Human associative memory. Washington, DC: V.H. Winston.

BALOTA, D. (1983). Automatic semantic activation and episodic memory encoding. Journal of Verbal Learning \& Verbal Behavior, 22, 88-104.

BeCKer, C. A. (1979). Semantic context and word frequency effects in visual word recognition. Journal of Experimental Psychology: Human Perception \& Performance, 3, 252-259.

BeCKer, C. A. (1980). Semantic context effects in visual word recognition: An analysis of semantic strategies. Memory \& Cognition, 8 , 493-512.

Champagnol, R. (1975). Organization semantique et linguistique dans le rappel libre bilingue [Semantic and linguistic organization in bilingual free recall]. Année Psychologique, 73, 115-134.

ChEN, H.-C., \& NG, M.-L. (1989). Semantic facilitation and translation priming effects in Chinese-English bilinguals. Memory \& Cognition, 17, 454-462.

Collins, A. M., \& LofTus, E. (1975). A spreading-activation theory of semantic processing. Psychological Review, 82, 407-428.

DALRYMPLE-ALFORD, E. C. (1968). Interlingual interference in a colournaming task. Psychonomic Science, 10, 215-216.
DE Groot, A. M. B. (1984). Primed lexical decision: Combined effects of the proportion of related prime-target pairs and the stimulus onset asynchrony of prime and target. Quarterly Journal of Experimental Psychology, 36A, 253-280.

DE GROOT, A. M. B., \& NAS, G. L. (1991). Lexical representation of cognates and noncognates in compound bilinguals. Journal of Memory \& Language, 30, 90-123.

den Heyer, K., Briand, K., \& Dannenberg, G. (1983). Strategic factors in a lexical-decision task: Evidence for automatic and attentiondriven processes. Memory \& Cognition, 11, 374-381.

DurgunoĞlu, A. Y., \& Roediger, H. L., III (1987). Test differences in accessing bilingual memory. Journal of Memory \& Language, 26, 377-391.

DYER, F. N. (1971). Colour naming interference in monolinguals and bilinguals. Joumal of Verbal Learning \& Verbal Behavior, 10, 297-302.

Glanzer, M., \& Duarte, A. (1971). Repetition between and within languages in free recall. Journal of Verbal Learning \& Verbal Behavior, 10, 625-630.

GoGgIN, J., \& WICKENS, D. D. (1971). Proactive interference and language change in short-term memory. Journal of Verbal Learning \& Verbal Behavior, 10, 453-458.

Grainger, J., \& Beauvillain, C. (1988). Associative priming in bilinguals: Some limits of interlingual facilitation effects. Canadian Joumal of Psychology, 42, 261-273.

JIN, Y.-S. (1990). Effects of concreteness on cross-language priming of lexical decision. Perceptual \& Motor Skills, 70, 1139-1154.

KeATLEY, C. W. (1987). Cross-language facilitation on the primed lexical decision task. Unpublished doctoral dissertation, University of Hong Kong.

KEATLEY, C. W. (1992). History of bilingualism research in cognitive psychology. In R. Harris (Ed.), Cognitive processing in bilinguals (pp. 15-50). Amsterdam: Elsevier.

Keatley, C. W., \& DE Gelder, B. (1992). The bilingual primed lexical decision task: Cross-language priming disappears with speeded responses. European Journal of Cognitive Psychology, 4, 273-292.

Kirsner, K., Smith, M., Lockhart, R., King, M., Jain, M. (1984). The bilingual lexicon: Language specific units in an integrated network. Journal of Verbal Leaming \& Verbal Behavior, 23, 519-539.

Kolers, P. A. (1963). Interlingual word associations. Journal of Verbal Learning \& Verbal Behavior, 2, 291-300.

Kolers, P. A. (1966). Reading and talking bilingually. American Journal of Psychology, 79, 357-377.

Kolers, P. A., Roediger, H. L., III (1984). Procedures of mind. Journal of Verbal Learning \& Verbal Behavior, 23, 425-449.

Kroll, J. F., CurLeY, J. (1988). Lexical memory in novice bilinguals: The role of concepts in retrieving second language words. In M. Gruneberg, P. Morris, \& R. Sykes (Eds.), Practical aspects of memory (Vol. 2). London: Wiley.

KROLL, J. F., STEWART, E. (1990). Concept mediation in bilingual translation. Paper presented at the annual meeting of the Psychonomic Society, New Orleans.

LoPez, M., Hicks, R. E., \& Young, R. K. (1974). Retroactive inhibition in a bilingual $\mathrm{a}-\mathrm{b}, \mathrm{a}^{\prime}-\mathrm{b}^{\prime}$ paradigm. Joumal of Experimental Psychology, 103, 85-90.

LOPEZ, M., \& Young, R. K. (1974). The linguistic interdependence of bilinguals. Journal of Experimental Psychology, 102, 981-983.

MACNAMARA, J. (1967). The linguistic independence of bilinguals. Journal of Verbal Learning \& Verbal Behavior, 6, 729-736.

MCLEOD, C. M. (1976). Bilingual episodic memory: Acquisition and forgetting. Journal of Verbal Learning \& Verbal Behavior, 15, 347-364.

MEYeR, D. E., \& RUDDY, M. G. (1974). Bilingual word-recognition: Organization and retrieval of alternative lexical codes. Paper presented at the meeting of the Eastern Psychological Association, Philadelphia.

Meyer, D. E., \& SchvaneveldT, R. W. (1971). Facilitation in recognizing pairs of words: Evidence of a dependence between retrieval operations. Journal of Experimental Psychology, 90, 227-234.

NeeLy, J. H. (1977). Semantic priming and retrieval from lexical memory: Roles of inhibitionless spreading activation and limited-capacity attention. Journal of Experimental Psychology: General, 106, 1-66. 
NeELY, J. H. (1990). Semantic priming effects in visual word recognition: A selective review of current findings and theories. In D. Besner \& G. Humphreys (Eds.), Basic processes in reading: Visual word recognition. Hillsdale, $\mathrm{NJ}$ : Erlbaum.

NoTT, R. C., \& LAMBERT, W. E. (1968). Free recall in bilinguals. Journal of Verbal Learning \& Verbal Behavior, 7, 1065-1071.

PaIvio, A. (1971). Imagery and verbal processes. Toronto: Holt, Rinehart \& Winston.

PAIVIO, A. (1986). Mental representations: A dual-coding approach. Oxford: Oxford University Press.

Paivio, A., \& Begg, I. (1981). Psychology of language. Englewood Cliffs, NJ: Prentice-Hall.

Paivio, A., Clark, J. M., \& Lambert, W. E. (1988). Bilingual dualcoding theory and semantic repetition effects on recall. Journal of Experimental Psychology: Learning, Memory, \& Cognition, 14, $163-172$.

Paivio, A., \& Desrochers, A. (1980). A dual-coding approach to bilingual memory. Canadian Journal of Psychology, 34, 388-399.

Pajvio, A., \& LAMBerT, W. E. (1981). Dual-coding and bilingual memory. Journal of Verbal Learning \& Verbal Behavior, 20, 532-539.

POSNER, M. (1978). Chronometric explorations of mind. Hillsdale, NJ: Erlbaum.

Posner, M., \& SNyder, C. (1975). Facilitation and inhibition in the processing of signals. In P. Rabbitt \& S. Dornic (Eds.), Attention and performance V (pp. 669-683). New York: Academic Press.

PotTeR, M. C. (1979). Mundane symbolism: The relations among objects, names, and ideas. In N. R. Smith \& M. B. Franklin (Eds.), Symbolic functioning in childhood (pp. 41-65). Hillsdale, NJ: Erlbaum.

Potter, M. C., Kroll, J. F., Yachzel, B., Carpenter, E., \& SherMAN, J. (1986). Pictures in sentences: Understanding without words. Journal of Experimental Psychology: General, 115, 281-294.

Potter, M. C., So, K.-F., Von Eckardt, B., \& Feldman, L. B. (1984). Lexical and conceptual representation in beginning and proficient bilinguals. Journal of Verbal Learning \& Verbal Behavior, 23, 23-38

Preston, M. S., \& LAMBerT, W. E. (1969). Interlingual interference in a bilingual version of the Stroop colour-word task. Journal of Verbal Learning \& Verbal Behavior, 8, 295-301.

RATCLIFF, R., \& McKoon, G. (1988). A retrieval theory of priming in memory. Psychological Review, 95, 385-408.

Rose, R. G., \& CARRolL, J. F. (1974). Free recall of a mixed language list. Bulletin of the Psychonomic Society, 3, 267-268.

SACK, A., \& YourMan, J. (1975). The Sack-Yourman developmental speed-reading course. New York: Speed Reading Institute.

Saegert, J., Hamayan, E., \& Ahmar, H. (1975). Memory for language of input in polyglots. Journal of Experimental Psychology: $\mathrm{Hu}$ man Learning \& Memory, 1, 607-613.

Sanchez-Casas, R. M., Davis, C. D., \&arcia-Albea, J. E. (1992). Bilingual lexical processing: Exploring the cognate/noncognate distinction. European Journal of Cognitive Psychology, 4, 293-310.

SAVARD, J. G., \& RichaRDS, J. (1970). Les indices dutilité du vocabulaire fondamental français. Quebec: Les Presses de l'Université Laval.

SChWANENFlugel, P., \& REY, M. (1986). Interlingual semantic facilitation: Evidence for a common representational system in the bilingual lexicon. Journal of Memory \& Language, 25, 605-618.

SNODGRASs, J. G. (1984). Concepts and their surface representations. Journal of Verbal Learning \& Verbal Behavior, 23, 3-22.

TAYLOR, I. (1971). How are words from two languages organized in bilingual memory? Canadian Journal of Psychology, 25, 228-240.

TWEEDY, J. R., \& LAPINSKI, R. H. (1981). Facilitating word recognition: Evidence for strategic and automatic factors. Quarterly Journal of Experimental Psychology, 33A, 51-59.

Tweedy, J. R., Lapinski, R. H., \& SchVaneveldt, R. W. (1977). Semantic-context effects on word recognition: Influence of varying the proportion of items presented in an appropriate context. Memory \& Cognition, 5, 84-89.

UIT DEN BOOGAART, P. C. (1975). Woordfrequenties in Geschreven en Gesproken Nederlands. Utrecht: Oosthoek, Scheltema \& Holkema.

Young, R. K., \& SAEGERT, J. (1966). Transfer with bilinguals. Psychonomic Science, 6, 161-162.

Young, R. K., \& Webrer, A. (1967). Positive and negative transfer with bilinguals. Journal of Verbal Learning \& Verbal Behavior, 6 , 874-877.

APPENDIX A

Stimulus Materials From Experiment 1

\begin{tabular}{|c|c|c|c|}
\hline Prime & & Target & \\
\hline black & 黑 & white & $\Leftrightarrow$ \\
\hline blood & 血 & red & $\pi 工$ \\
\hline blow & 吹 & wind & 19 \\
\hline climb & 樊 & mountain & 4 \\
\hline come & & go & \\
\hline copy & titt & write & 窟 \\
\hline cough & वर्य & sick & \\
\hline crab & & shrimp & \\
\hline $\operatorname{dog}$ & & cat & 多 \\
\hline drink & & water & \\
\hline east & & west & 画 \\
\hline
\end{tabular}




\begin{tabular}{|c|c|c|c|}
\hline \multicolumn{4}{|c|}{ APPENDIX A (Continued) } \\
\hline Prime & & Target & \\
\hline far & 㟟 & near & \\
\hline fast & 快 & slow & \\
\hline empty & & full & \\
\hline few & & many & \\
\hline fly & & bird & \\
\hline fork & & knife & \\
\hline good & & bad & \\
\hline hat & & head & \\
\hline hand & & foot & \\
\hline listen & 节贯 & ear & \\
\hline heavy & 䒠 & light & \\
\hline kick & & ball & \\
\hline $\operatorname{lamp}$ & & glow & \\
\hline leaf & 萎 & tree & \\
\hline love & 爱 & hate & \\
\hline low & 低 & high & \\
\hline new & 栾 & old & \\
\hline up & 上 & down & \\
\hline page & & book & \\
\hline pay & 1 & money & \\
\hline push & 推 & pull & \\
\hline return & & home & 家 \\
\hline right & & wrong & \\
\hline round & & square & \\
\hline row & & boat & 船 \\
\hline salt & & salty & 武成 \\
\hline send & 害 & letter & 信 \\
\hline shallow & & deep & 深 \\
\hline
\end{tabular}


APPENDIX A (Continued)

\begin{tabular}{|c|c|c|c|}
\hline Prime & & Target & \\
\hline shore & 岸 & sea & \\
\hline short & 短 & long & \\
\hline sing & 唱 & song & \\
\hline small & 1) & big & \\
\hline soft & 事 & hard & \\
\hline subtract & $三 V_{X}$ & add & \\
\hline sugar & 䊒 & sweet & \\
\hline thief & 恩戎 & steal & \\
\hline thin & 瘁 & fat & 肥 \\
\hline true & 真 & false & 假 \\
\hline table & 枱 & chair & 才 \\
\hline warm & 日爱 & cold & \\
\hline wet & 濕 & dry & 乾 \\
\hline wide & 鹪 & narrow & 焦 \\
\hline win & 期 & lose & 輸 \\
\hline
\end{tabular}

APPENDIX B

Stimulus Materials From Experiment 2

Dutch

1.

2.

3.

4.

5.

6.

7.

8.

9.

10.

11.

12.

13.

14.

15.

16.

17.

18. aankoop/verkoop

ademen/lucht

antwoord/vraag

appel/peer

bed/slapen

begin/einde

bestaan/leven

betalen/geld

bidden/kerk

bloed/rood

borstel/haar

$\mathrm{breed} / \mathrm{smal}$

broer/zus

bron/water

dag/nacht

dichtbij/veraf

dik/dun

doof/stom
French

achat/vente

respirer/air

réponse/question

pomme/poire

lit/dormir

début/fin

exister/vivre

payer/argent

prier/église

sang/rouge

brosse/cheveux

large/étroit

frère/soeur

source/eau

jour/nuit

proche/loin

gros/mince

sourd/muet
English

Translation

(buy/sell)

(breathe/air)

(answer/question)

(apple/pear)

(bed/sleep)

(beginning/end)

(exist/live)

(pay/money)

(pray/church)

(blood/red)

(brush/hair)

(wide/narrow)

(brother/sister)

(spring/water)

(day/night)

(near/far)

(thick/thin)

(deaf/dumb) 
APPENDIX B (Continued)

\begin{tabular}{|c|c|c|c|}
\hline 19. & dorst/drinken & soif/boire & (thirst/drink) \\
\hline 20. & droog/nat & sec/mouillé & (dry/wet) \\
\hline 21. & gekheid/zot & folie/fou & (insanity/insane) \\
\hline 22 . & geloven/god & croire/dieu & (believe/god) \\
\hline 23. & gezicht/ogen & visage/yeux & (face/eyes) \\
\hline 24. & gisteren/verleden & hier/passé & (yesterday/past) \\
\hline 25. & glijden/ijs & glisser/glace & (skate/ice) \\
\hline 26. & goed/slecht & bon/mauvais & $(\operatorname{good} / \mathrm{bad})$ \\
\hline 27. & gordijn/raam & rideau/fenêtre & (curtain/window) \\
\hline 28, & graan/brood & blé/pain & (wheat/bread) \\
\hline 29. & gras/groen & herbe/vert & (grass/green) \\
\hline 30. & grond/aarde & sol/terre & (ground/earth) \\
\hline 31. & haan/kip & coq/poulet & (rooster/chicken) \\
\hline 32. & hart/liefde & coeur/amour & (heart/love) \\
\hline 33. & haven/boten & port/bateau & (port/boat) \\
\hline 34. & hemel/blauw & $\mathrm{ciel} / \mathrm{bleu}$ & (sky/blue) \\
\hline 35. & hesp/vlees & jambon/viande & (ham/meat) \\
\hline 36. & honing/bij & miel/abeille & (honey/bee) \\
\hline 37. & jong/oud & jeune/vieux & (young/old) \\
\hline 38. & jongen/meisje & garçon/fille & (boy/girl) \\
\hline 39. & kalf/koe & veau/vache & (calf/cow) \\
\hline 40. & kameel/woestijn & chameau/désert & (camel/desert) \\
\hline 41. & kelder/wijn & cave/vin & (cellar/wine) \\
\hline 42. & klein/groot & petit/grand & (little/big) \\
\hline 43. & knie/been & genou/jambe & (knee/leg) \\
\hline 44. & koorts/ziek & fièvre/malade & (fever/sick) \\
\hline 45. & koud/warm & froid/chaud & (cold/hot) \\
\hline 46. & laag/hoog & bas/haut & (low/high) \\
\hline 47. & laaste/eerste & dernier/premier & (last/first) \\
\hline 48. & leeg/vol & vide/plein & (empty/full) \\
\hline 49. & leerling/school & éleve/école & (student/school) \\
\hline 50. & les/leren & leçon/étudier & (lesson/study) \\
\hline 51. & lezen/boek & lire/livre & (read/book) \\
\hline 52. & links/rechts & gauche/droite & (left/right) \\
\hline 53. & maand/jaar & mois/année & (month/year) \\
\hline 54. & maatijd/eten & repas/manger & (meal/eat) \\
\hline 55. & misdaad/moord & crime/meurtre & (crime/murder) \\
\hline 56. & muis/kat & souris/chat & (mouse/cat) \\
\hline 57. & oost/west & est/ouest & (east/west) \\
\hline 58. & peper/zout & poivre/sel & (pepper/salt) \\
\hline 59. & pers/krant & presse/journal & (press/newspaper) \\
\hline 60. & postbode/brief & facteur/lettre & (bill/letter) \\
\hline 61. & rekenen/wiskunde & calculer/math & (calculate/math) \\
\hline 62. & zingen/lied & chanter/chanson & (sing/song) \\
\hline 63. & rijden/auto & rouler/voiture & (ride/car) \\
\hline 64. & schaap/wol & mouton/laine & (sheep/wool) \\
\hline 65. & schaar/knippen & ciseaux/couper & (scissors/cut) \\
\hline 66. & schijnen/zon & briller/soleil & (shine/sun) \\
\hline 67. & sleutel/deur & clef/porte & (key/door) \\
\hline 68. & snel/vlug & rapide/vite & (rapid/fast) \\
\hline 69. & spelen/kinderen & jouer/enfants & (play/children) \\
\hline 70. & spijker/hamer & clou/marteau & (nail/hammer) \\
\hline 71. & stoel/tafel & chaise/table & (chair/table) \\
\hline 72. & strand/zee & plage/mer & (beach/sea) \\
\hline 73. & tak/boom & branche/arbre & (branch/tree) \\
\hline 74. & tijdperk/eeuw & époque/siècle & (epoch/century) \\
\hline 75. & top/berg & sommet/montagne & (summit/mountain) \\
\hline 76. & tuin/bloemen & jardin/fleurs & (garden/flowers) \\
\hline 77. & vader/moeder & père/mère & (father/mother) \\
\hline 78. & vertrek/aankomst & départ/arrivée & (departure/arrival) \\
\hline 79. & vijand/vriend & ennemi/ami & (enemy/friend) \\
\hline 80. & vinger/hand & doigt/main & (finger/hand) \\
\hline 81. & vleugel/vogel & aile/oiseau & (wing/bird) \\
\hline
\end{tabular}


APPENDIX B (Continued)

\begin{tabular}{|c|c|c|c|}
\hline 82. & vrouw/man & femme/homme & (woman/man) \\
\hline 83. & wapen/oorlog & arme/guerre & (weapon/war) \\
\hline 84. & wild/dieren & sauvage/animal & (wild/animal) \\
\hline 85. & winkel/kopen & magasin/acheter & (store/buy) \\
\hline 86. & winter/sneeuw & hiver/neige & (winter/snow) \\
\hline 87. & woede/kwaad & colère/fâché & (anger/angry) \\
\hline 88. & woord/zin & mot/phrase & (word/sentence) \\
\hline 89. & woud/bos & forêt/bois & (forest/wood) \\
\hline 90. & zeep/wassen & savon/laver & (soap/wash) \\
\hline 91. & zeggen/praten & dire/parler & (say/speak) \\
\hline 92. & zetel/zitten & fauteuil/s'assoir & (armchair/sit) \\
\hline 93. & ziel/geest & âme/esprit & (soul/spirit) \\
\hline 94. & zoeken/vinden & chercher/trouver & (seek/find) \\
\hline 95. & zwaar/licht & lourd/léger & (heavy/light) \\
\hline 96. & zwart/wit & noir/blanc & (black/white) \\
\hline
\end{tabular}

APPENDIX C

Translation-Equivalent Stimulus Materials From Experiment 3

\begin{tabular}{|c|c|c|c|}
\hline & Dutch & French & $\begin{array}{c}\text { English } \\
\text { Translation }\end{array}$ \\
\hline 1. & rund & boeuf & (ox) \\
\hline 2. & blind & aveugle & (blind) \\
\hline 3. & knop & bouton & (button) \\
\hline 4. & twijfel & doute & (doubt) \\
\hline 5. & kers & cerise & (cherry) \\
\hline 6. & zacht & doux & (soft) \\
\hline 7. & paard & cheval & (horse) \\
\hline 8. & honger & faim & (hunger) \\
\hline 9. & room & crème & (cream) \\
\hline 10. & klimmen & grimper & (climb) \\
\hline 11. & ladder & échelle & (ladder) \\
\hline 12. & vreugde & joie & (joy) \\
\hline 13. & zakdoek & mouchoir & (handkerchief) \\
\hline 14. & lelijk & laid & (ugly) \\
\hline 15. & aardbei & fraise & (strawberry) \\
\hline 16. & wet & loi & (law) \\
\hline 17. & keel & gorge & (throat) \\
\hline 18. & beter & meilleur & (better) \\
\hline 19. & meer & lac & (lake) \\
\hline 20. & helft & moitié & (half) \\
\hline 21. & wolf & loup & (wolf) \\
\hline 22. & hangen & pendre & (hang) \\
\hline 23. & stro & paille & (straw) \\
\hline 24. & diep & profond & (deep) \\
\hline 25. & brug & pont & (bridge) \\
\hline 26. & droom & rêve & (dream) \\
\hline 27. & golf & vague & (wave) \\
\hline 28. & drogen & sèche & (dry) \\
\hline 29. & fiets & vélo & (bike) \\
\hline 30. & week & semaine & (week) \\
\hline 31. & vuur & feu & (fire) \\
\hline 32. & avond & soir & (evening) \\
\hline 33. & arm & bras & (arm) \\
\hline 34. & bodem & fond & (bottom) \\
\hline 35. & doos & boîte & (box) \\
\hline 36. & ogenblik & instant & (moment) \\
\hline 37. & mes & couteau & (knife) \\
\hline
\end{tabular}


APPENDIX C (Continued)

$\begin{array}{llll}38 . & \text { herfst } & \text { automne } & \text { (autumn) } \\ 39 . & \text { tand } & \text { dent } & \text { (tooth) } \\ 40 . & \text { hoesten } & \text { tousser } & \text { (cough) } \\ 41 . & \text { bord } & \text { assiette } & \text { (plate) } \\ 42 . & \text { gevaar } & \text { danger } & \text { (danger) } \\ 43 . & \text { konijn } & \text { lapin } & \text { (rabbit) } \\ 44 . & \text { gedicht } & \text { poème } & \text { (poem) } \\ 45 . & \text { kast } & \text { armoire } & \text { (wardrobe) } \\ 46 . & \text { zomer } & \text { été } & \text { (summer) } \\ 47 . & \text { vlieg } & \text { mouche } & \text { (fly) } \\ 48 . & \text { laat } & \text { tard } & \text { (late) }\end{array}$

(Manuscript received April 13, 1990

revision accepted for publication June 30, 1993.) 